\title{
ENZYME ACTIVITY AND TIME-COURSE QUANTITATIVE DISTRIBUTION OF AN ORAL DOSE OF IMIDACLOPRID IN MALE RAT TISSUES
}

\author{
Heba E. Nasr ${ }^{1 *}$, A.A. Shalaby ${ }^{1}$, D.A.Ragheb ${ }^{1}$, M.Y. Hendawi ${ }^{1}$ and Sébastien Sauvé ${ }^{2}$ \\ 1. Plant Prot. Dept., Fac. Agric., Zagazig Univ., Egypt \\ 2. Chem. Dept., Univ. de Montréal, Canada
}

Received: 15/07/2019 ; Accepted: 04/08/2019

\begin{abstract}
The purpose of this study was to investigate the time course of changes in enzymes activity during distribution of imidaclopride (IMI) in Male Albino rat (Rattus norvegicus) after 1, 3, 6, 12, 24 and $48 \mathrm{hr}$., treatment with a single oral dose $(20 \mathrm{mg} / \mathrm{kg}$ body weight). The results showed significant gradual increase in liver and kidney function parameters coincided with accumulation of imidacloprid with varying quantities according to each organ, then gradually decreased to the end of study. The highest activity in liver enzymes, ALT (97.33 U/L), AST (78 U/L) ALP (169.66 IU/L) and LDH (5190.67 U/L) was recorded six hours post treatment, as well as increasing in total protein (8.94 g/dl). Kidney function parameters, i.e. urea, creatinine and uric acid levels $(75.67,2.283,19.15 \mathrm{mg} / \mathrm{dl}$, respectively) were also revealed the highest increase comparing with control. Liver and brain acetylcholinesterase (AChE) activity was reached the lowest level with the inhibition percent 82.9, $81.4 \%$, respectively at the same time agreed with the concentration peak of IMI in blood $(8.04 \mu \mathrm{g} / \mathrm{ml})$ liver $(2.42 \mu \mathrm{g} / \mathrm{g})$ and brain $(4.06 \mu \mathrm{g} / \mathrm{g})$. The trend of maximal concentration of IMI in different organs and body fluids at six hours post dosing was in the following order: urine $>$ blood $>$ lungs $>$ brain $>$ testes $>$ spleen $>$ kidney $>$ liver $>$ muscles.
\end{abstract}

Key words: Imidacloprid, time-course, residues, enzymes, QuEChERS, male rats.

\section{INTRODUCTION}

Neonicotinoids group is a new class of systemic insecticides having the same structure and action of nicotine, therefore acts as agonists at the insect nicotinic acetylcholine receptors (nAChRs) in post synaptic (Yamamoto et al., 1998; Matsuda et al., 2001).

Among them, imidacloprid (IMI) is being the first compound introduced into the global market since 1991 (Moriya et al., 1992). It is moderately toxic and its acute oral $\mathrm{LD}_{50}$ is 450 $\mathrm{mg} / \mathrm{kg}$ for rats and $150 \mathrm{mg} / \mathrm{kg}$ for mice (Tomlin, 1997). Due to increasing use of IMI in agriculture to control piercing-sucking insect pests, its residue may occur in foods, fruits and vegetables, and therefore, pose a potential hazard for consumers (Watanabe et al., 2007). IMI, according to the Environmental Protection
Agency, has the potential to leach into groundwater and runoff due to its high solubility $(0.61 \mathrm{~g} / \mathrm{l})$ and mobility which contaminate water. IMI has selective toxicity resulted from its high affinity to insect's nicotinic acetylcholine receptors versus mammals (Tomizawa and Casida, 2005). The liver is the principal target organ of imidacloprid toxicity, as demonstrated by elevation of serum activities of aspartate aminotransferase (AST), alkaline phosphatase (ALP) and lactate dehydrogenase. Exposure to $1 / 100 \mathrm{LD}_{50}$ of IMI induces immunotoxicity, oxidative stress, lipid peroxidation and hepatotoxicity in male rats (Rahman et al., 2000; Mohany et al., 2011). IMI caused significant decrease in acetylcholinesterase activity in brain and plasma after oral dose for 60 days (Vohra et al., 2014). IMI has toxicological effect at a dose level of 20

\footnotetext{
*Corresponding author: Tel. : +201018114423

E-mail address: hebanasr580@gmail.com
} 
$\mathrm{mg} / \mathrm{kg} /$ day after 90 days oral administration, causing damages in morphology of ovary, ovarian hormones, and the activity of antioxidant enzymes in female rats. IMI at 5 and $10 \mathrm{mg} / \mathrm{kg} / \mathrm{day}$ has not produced any significant changes and induced significant effects on body weight, liver and kidney functions at $15 \mathrm{mg} / \mathrm{kg} /$ day to mice (Kapoor et al., 2011; Arfat et al., 2014). Tissue disposition can provide important information on the time-course of compound transfer from one tissue compartment to another. Kapoor et al. (2014) used QuEChERS, which stands for quick, easy, cheap, effective, rugged, and safe method for analysis the residues of IMI in different organs (liver, brain, kidney and ovary) and body fluids (blood, urine and faeces). Taliansky-Chamudis et al. (2017) showed that QuEChERS is a successful technique for analysis of neonicotinoids including IMI in blood of eagle owls. They found a good range of recoveries ensuring the use of these techniques for monitoring studies successfully. Increasing use of imidacloprid and its potential toxicity among human heightened its warrants toward awareness. The objective of the current study is to evaluate the time course effect following single oral dose of IMI in male rat tissues and blood. Thus, we have tried to correlate the tissue concentration of IMI with tissue disposition and biochemical effects.

\section{MATERIALS AND METHODS}

\section{Animals}

Male albino Wistar rats (Rattus norvegicus) weighing $160 \pm 10 \mathrm{~g}$ were obtained from the Laboratory Animal Housing Unit, Faculty of Veterinary Medicine, Zagazig University, Egypt, and acclimatized for 2 weeks prior to the experiment in plastic cages under laboratory conditions $\left(22 \pm 3^{\circ} \mathrm{C}\right.$, relative humidity $65 \pm 5 \%$ and a $12 \mathrm{hr}$., light/dark cycle). Rats were treated individually in metabolic cages with free access to food and water. All experimental procedures were approved by the Institutional Animal Care and Use Committee, Zagazig University (ZUIACUC) (Number: ZU-IACUC/2/F/59/2018).

\section{Insecticide}

A technical grade sample of Imidacloprid $98 \%$ ((E) - 1 - (6 - chloro - 3 - pyridylmethyl)
-N - nitroimidazolidin -2 - ylideneamine) was obtained from Sumitomo Chemicals Co.Ltd.<smiles>O=[N+]([O-])NC1=NCCN1Cc1ccc(Cl)nc1</smiles>

Fig. 1. Chemical structure of imidacloprid

\section{Chemicals}

Acetonitrile, HPLC grade (POUCH SA, Gliwice, Poland); glacial acetic acid (El-Nasr Pharmaceutical Chemicals Co., Abu-Zaabal, Cairo, Egypt); primary secondary amine (PSA), C18 and anhydrous magnesium sulfate $\left(\mathrm{MgSO}_{4}\right)$ for QuEChERS kits purchased from Agilent Technologies Co. (USA). Aspartate aminotransferase (AST), alanine aminotransferase (ALT) and alkaline phosphatase (ALP), lactate dehydrogenase (LDH), total protein, Blood urea nitrogen (BUN), uric acid, creatinine and Acetylcholinesterase (AChE) kits were obtained from Bio-diagnostic Chemical Company, Cairo, Egypt.

\section{Animals Treatment}

A single oral dose from Imidacloprid (IMI) (20 mg/kg b. wt.) $1 / 22$ of $\mathrm{LD}_{50}$ was dissolved in corn oil as vehicle and administered to rats. Sixty animals were randomly divided into two groups. Group I (30 rats) served as vehicle control and was given corn oil $(0.4 \mathrm{ml} / \mathrm{rat})$ through gavage. Group II (30 rats) was orally administered IMI $(20 \mathrm{mg} / \mathrm{kg}$ b. wt.) suspended in corn oil in single dose with equal volume of oil per rat. Five animals from control and five animals from treated groups were sacrificed at 1 , $3,6,12,24$ and $48 \mathrm{hr}$.

\section{Blood and Tissue Samples}

At each time point, two blood samples were immediately collected from each rat. The first sample collected into heparinized tubes for IMI residues analysis. The second sample was collected in a non-heparinized tube and centrifuged for $10 \mathrm{~min}$ at $3000 \mathrm{rpm}$ to separate the serum, which was then stored at $-20^{\circ} \mathrm{C}$ for further biochemical analysis. Liver, kidney, testes, lungs, muscles spleen and brain organs were removed after dissection. However urine 
samples were collected at $6 \mathrm{hr}$., $12 \mathrm{hr}$., $24 \mathrm{hr}$. and $48 \mathrm{hr}$. All samples were stored at $-20^{\circ} \mathrm{C}$ until analysis.

\section{Biochemical Analyses}

\section{Liver and kidney biomarkers}

Liver and kidney function biomarkers; serum Aspartate aminotransferase (AST), alanine aminotransferase (ALT) activities and alkaline phosphatase (ALP) activity were determined colorimetrically, using UV-VIS spectrophotometer (Perkin-Elmer 550 SE, Germany) at 546, 546 and $510 \mathrm{~nm}$, respectively according to Henry (1964). Lactate dehydrogenase (LDH) activity as an indicator of necrotic cell death was determined using diagnostic kit according to Vassault (1986). Total protein was measured colorimetrically according to the method of Vassault (1986) using the kit obtained from Bio-diagnostics. Creatinine, uric acid and blood urea nitrogen (BUN) were measured colorimetrically according to the method of Henry (1974), Trinder (1969) and Chaney and Marbach (1962), respectively.

\section{Acetylcholinesterase (AChE) activity}

Acetylcholinesterase (AChE) activity was measured in liver and brain with a colorimetric method according to the method of Ellman et al. (1961).

\section{Residue Analyses}

Imidacloprid residues in blood, liver, kidney, spleen, brain, lung, muscles and urine were determined. Three samples from each organ were extracted and cleaned up using QuEChERS modified method according to Lehotay (2007) and Kapoor et al. (2014). The residues of IMI were determined using HPLC system (Agilent, USA) model 1100 series with the following conditions: a binary pump and auto sampler, UV (Ultra violet detector), BDS $\mathrm{C}_{18}$ Equisil column $(4.6 \mathrm{~mm} \quad$ (id) $\times 150 \mathrm{~mm}$ length) and the mobile phase was distilled water and acetonitrile $(30: 70, V / V)$. The flow rate was maintained at $1.0 \mathrm{ml} / \mathrm{min}$ and the injection volume was $10 \mu 1$. IMI was detected at $270 \mathrm{~nm}$ at retention time $2.9 \mathrm{~min}$. Results were corrected using their respective recovery rates.

\section{Statistical Analysis}

Data of biochemical and residues analyses were presented as the mean \pm standard deviation. Co-Stat Windows software package was used for statistical analyses. Duncan and Tukey-Test at $\mathrm{P}<0.05$ were assessed as statistical significance (Anonymous, 1986).

\section{RESULTS AND DISCUSSION}

\section{Tissue Distribution of Imidacloprid in Rats}

Results in Table 1 show the detected residue amounts of IMI in different organs and body fluids of male Wister albino rats after 1, 3, 6, 12, 24 and $48 \mathrm{hr}$., of oral administration. There was a rapid distribution of the insecticide IMI in rat tissues one hour after single oral administration $(20 \mathrm{mg} / \mathrm{kg} \mathrm{b}$. wt.). Residues in the tested tissues at $48 \mathrm{hr}$., after dosing recorded minimal concentrations. After 6 hours, the general trend of maximal concentration of IMI residues was in the following order: urine $>$ blood $>$ lung $>$ brain $>$ testes $>$ spleen $>$ kidney $>$ liver $>$ muscles. The level of IMI was 25.62 and 8.04 $\mu \mathrm{g} / \mathrm{ml}$ in urine and blood and 7.52, 4.06, 3.99, $3.79,3.14,2.42$ and $2.05 \mu \mathrm{g} / \mathrm{g}$ in lung, brain, testes, spleen, kidney, liver, muscles, respectively. As shown in Table 1 when time elapsed, the concentrations of IMI in the tested tissues were increased to reach the maximum amounts after 6 hours with the exception of muscles and urine (after $12 \mathrm{hr}$ ), which indicates the absorption of IMI in rats reached to saturation post dosing, then decreased gradually to reach to the minimum detected amounts at the end of the experimental period (48 hr.) in blood, urine, lung, brain, spleen, kidney, liver, testes and muscles recording $0.19,1.87,0.16,0.09$, $0.09,0.11,0.21,0.12$ and $2.13 \mu \mathrm{g} / \mathrm{ml}$ or $\mathrm{g}$, respectively.

Results also revealed that the concentration in the muscles $(0.07 \mu \mathrm{g} / \mathrm{g})$ was lower than the other organs, i.e. blood, lung, brain, spleen, kidney, liver and testes after one hour post dosing $(2.81,3.24,1.89,2.08,1.51,0.59$ and $0.29 \mu \mathrm{g} / \mathrm{g}$ or $\mathrm{ml}$, respectively). The pattern of distribution of IMI in different organs and body fluids was varied, however, the occurrence of peak levels of IMI at the $6 \mathrm{hr}$., time 
Table 1. Distribution of imidacloprid in different organs and body fluids of male Wister albino rats following single oral administration $(20 \mathrm{mg} / \mathrm{kg}$ body weight $)$

\begin{tabular}{lcccccc}
\hline Sample & \multicolumn{6}{c}{ Detected amount $(\boldsymbol{\mu g} / \mathbf{g}$ or $\boldsymbol{\mu g} / \mathbf{m l})$ of imidacloprid at" } \\
\cline { 2 - 7 } & $\mathbf{1 ~ h r}$. & $\mathbf{3 ~ h r}$. & $\mathbf{6 ~ h r}$. & $\mathbf{1 2} \mathbf{~ h r}$. & $\mathbf{2 4} \mathbf{~ h r}$. & $\mathbf{4 8} \mathbf{~ h r}$. \\
\hline Blood & $2.81 \pm 0.16$ & $4.06 \pm 0.04$ & $8.04 \pm 0.18$ & $3.76 \pm 0.17$ & $0.35 \pm 0.001$ & $0.19 \pm 0.002$ \\
Brain & $1.89 \pm 0.18$ & $2.13 \pm 1.09$ & $4.06 \pm 1.04$ & $1.72 \pm 0.30$ & $0.19 \pm 0.01$ & $0.09 \pm 0.01$ \\
Liver & $0.59 \pm 0.06$ & $0.85 \pm 0.03$ & $2.42 \pm 0.04$ & $0.78 \pm 0.01$ & $0.39 \pm 0.05$ & $0.21 \pm 0.02$ \\
Kidney & $1.51 \pm 0.01$ & $1.80 \pm 0.14$ & $3.14 \pm 0.06$ & $1.59 \pm 0.02$ & $0.13 \pm 0.002$ & $0.11 \pm 0.02$ \\
Spleen & $2.08 \pm 0.05$ & 2.670 .02 & $3.79 \pm 0.03$ & $1.05 \pm 0.01$ & $0.29 \pm 0.03$ & $0.09 \pm 0.01$ \\
Testes & $0.29 \pm 0.03$ & $1.21 \pm 0.22$ & $3.99 \pm 0.13$ & $1.86 \pm 0.19$ & $0.19 \pm 0.01$ & $0.12 \pm 0.002$ \\
Muscles & $0.07 \pm 0.01$ & $0.51 \pm 0.61$ & $2.05 \pm 0.32$ & $5.55 \pm 0.41$ & $2.26 \pm 0.06$ & $2.13 \pm 0.11$ \\
Lung & $3.24 \pm 0.07$ & $5.95 \pm 0.01$ & $7.52 \pm 0.03$ & $3.13 \pm 0.08$ & $0.32 \pm 0.01$ & $0.16 \pm 0.03$ \\
Urine & $\mathrm{NA}^{* *}$ & $\mathrm{NA}$ & $25.62 \pm 0.18$ & $31.96 \pm 2.86$ & $13.55 \pm 0.29$ & $1.87 \pm 0.001$ \\
\hline
\end{tabular}

* Detected amounts of imidacloprid in blood and urine $(\mu \mathrm{g} / \mathrm{ml})$ while in the rest samples $(\mu \mathrm{g} / \mathrm{g})$.

** samples from urine were not collected after 1 and $3 \mathrm{hr}$., of treatment.

point in all tissues suggests that IMI was rapidly absorbed, distributed, metabolized and excreted after oral administration as indicated by its presence in blood, urine and organs. Protein binding in the blood can be assumed to play a significant role with IMI in illustrating its fate in the body for periods of time. These results are agree with those obtained by Brunet et al. (2004) who reported that IMI is highly absorbed in human intestinal cell suggesting its potential effects. No difference was found between female and male rats. Concentration peaks of IMI were attained by $6 \mathrm{hr}$ in all tissues, with the exception of the muscles and urine, $12 \mathrm{hr}$. Meanwhile, Kapoor et al. (2014) reported that the concentration of IMI was maximum attained at $12 \mathrm{hr}$., post dosing in organs (liver, brain, kidney and ovary) and body fluids (blood, faeces and urine) after the same dose $(20 \mathrm{mg} / \mathrm{kg}$ b. wt.) in female rats.

\section{Enzymes Activity}

With respect to enzymes activity, the levels generally agreed quite well with the presence in the target tissues, i.e., the greater the amounts of compound presents at the time point, the greater the levels of enzymes observed. It is clear that the presence of IMI, specifically at peak concentration, in the selected tissues appears to be a good indicator of enzymes reduction. A shift in the amount and rate of oral absorption may result in the observed alteration in the time course of both parent compound and its metabolites resulting an increase and delay in achieving to the maximum concentration (Timchalk et al., 2006). Changes in serum levels of AST, ALT, ALP and LDH enzymes and the levels of blood urea nitrogen (BUN), creatinine, uric acid and total protein showed a dose-related time course of IMI exposed groups. These results are in agreement with those obtained by Abu Zeid et al. (2019).

\section{Liver function}

The effect of IMI on serum levels of aspartate aminotransferase (AST), alanine aminotransferase (ALT), alkaline phosphatase (ALP) and lactate dehydrogenase (LDH) activities are shown in Table 2. The highest significant increase in enzymes activity was recorded $6 \mathrm{hr}$., after dosing, then less increase were observed up to the end time point, $48 \mathrm{hr}$., of the study.

Comparing with control, ALT, AST and ALP were significantly increased at all the time periods of the experiment after dosing. As for $\mathrm{LDH}$, the enzyme activity was increased significantly one hr. post dosing, whereas there were significant increases up to the end point; i.e. $48 \mathrm{hr}$. The increases in enzyme activities were not significant at 3 and $48 \mathrm{hr}$ for ALT and $\mathrm{LDH}$, as well as at 6 and $12 \mathrm{hr}$., with LDH only. 
Table 2. The effect of imidacloprid on liver enzymes in male rats after single oral administration ( $20 \mathrm{mg} / \mathrm{kg}$ body weight)

\begin{tabular}{ccccc}
\hline Time (hr.) & ALT (U/L) & AST (U/L) & ALP (IU/L) & LDH (U/L) \\
\hline Control & $15.66 \pm 1.25^{\mathrm{f}}$ & $24.33 \pm 2.05^{\mathrm{f}}$ & $68.66 \pm 2.49^{\mathrm{g}}$ & $2824.00 \pm 10.98^{\mathrm{d}}$ \\
$\mathbf{1}$ & $25.33 \pm 2.62^{\mathrm{e}}$ & $41.00 \pm 2.16^{\mathrm{d}}$ & $82.66 \pm 2.62^{\mathrm{f}}$ & $3114.17 \pm 131.61^{\mathrm{d}}$ \\
$\mathbf{3}$ & $39.66 \pm 3.39^{\mathrm{d}}$ & $51.66 \pm 2.87^{\mathrm{c}}$ & $98.66 \pm 6.01^{\mathrm{e}}$ & $3813.66 \pm 118.38^{\mathrm{c}}$ \\
$\mathbf{6}$ & $97.33 \pm 2.29^{\mathrm{a}}$ & $78.00 \pm 2.16^{\mathrm{a}}$ & $169.66 \pm 3.39^{\mathrm{a}}$ & $5190.67 \pm 77.14^{\mathrm{a}}$ \\
$\mathbf{1 2}$ & $82.00 \pm 3.74^{\mathrm{b}}$ & $64.00 \pm 3.27^{\mathrm{b}}$ & $146.00 \pm 5.89^{\mathrm{b}}$ & $4862.67 \pm 45.09^{\mathrm{a}}$ \\
$\mathbf{2 4}$ & $64.00 \pm 2.45^{\mathrm{c}}$ & $47.33 \pm 2.62^{\mathrm{c}}$ & $124.66 \pm 4.11^{\mathrm{c}}$ & $4357.66 \pm 477.09^{\mathrm{b}}$ \\
$\mathbf{4 8}$ & $41.67 \pm 2.87^{\mathrm{d}}$ & $33.00 \pm 3.56^{\mathrm{e}}$ & $113.00 \pm 4.55^{\mathrm{d}}$ & $3583.33 \pm 209.49^{\mathrm{c}}$
\end{tabular}

Values are mean \pm S.D. (n=5/group). Alanine aminotransferase (ALT), Aspartate aminotransferase (AST), Alkaline phosphatase (ALP), Lactate dehydrogenase (LDH).

Increasing in enzyme activities at $6 \mathrm{hr}$ may be due to the high accumulation of IMI at this time in the liver as it is the principal target organ for any foreign compound entering the body. These results are in agreement with those obtained by Bhardwaj et al. (2010), Balani et al. (2011), Mohany et al. (2011), Toor et al. (2013), Arfat et al. (2014), Kapoor et al. (2014) and Abu- Zeid et al. (2019).

\section{Kidney functions}

The effects of IMI on serum levels of blood urea nitrogen (BUN), creatinine, uric acid and total protein are shown in Table 3. There was significant increase in level of urea, uric acid and total protein, and insignificant increase in the level of creatinine after one hour post dosing single oral dose compared to control group. The levels continued to show significant increase until reached to the time of peak effect at $6 \mathrm{hr}$., after dosing, while their levels significantly $(\mathrm{p}<0.05)$ decreased after $12 \mathrm{hr}$., up to the end of the experimental period $(48 \mathrm{hr}$.). The results suggest that the higher accumulation of IMI at 6 $\mathrm{hr}$., cause significant increase in the levels of (BUN), creatinine, uric acid and total protein but at the end of study these levels decreased and reached to the normal level that does not cause any toxicity. In this respect, Bhardwaj et al. (2010) studied the IMI nephrotoxicity and found tubular changes in the kidney in rats when exposed to higher dose.
Arfat et al. (2014) also found that higher doses of IMI increased tubular changes and show its nephrotoxicity in mice. However, the kidneys, the major detoxification organ for many xenobiotics, are frequently susceptible to the nephrotoxic effects. We also found that higher accumulation of imidacloprid after $6 \mathrm{hr}$., of administration caused significant changes in the kidney function.

\section{Acetylcholinesterase activity}

Liver and brain acetylcholinesterase activity are shown in Table 4. There was a significant reduction in the level of acetylcholinesterase activity after one hour post dosing single oral dose compared to control group. The reduction level continued to show significant increase until reached the time of minimal level at $6 \mathrm{hr}$., post dosing, then the rate of reduction of enzyme activity was lesser in the followed time intervals up to the end point time; i.e. $48 \mathrm{hr}$., of the study.

The extent of AChE inhibition was almost comparable in liver and brain at 3-24 hr., post dosing. The inhibition of $\mathrm{AChE}$ ranged from $21 \%$ to $82 \%$ in liver and $27-81 \%$ in brain as compared to the control. The reason of $\mathrm{AChE}$ inhibition is unknown because IMI is not $\mathrm{AChE}$ inhibitor, since plasma $\mathrm{AChE}$ is synthesized in the liver, the decrease in plasma AChE activity may be related to observed changes in liver function (California EPA, 2006). 
Table 3. Effect of imidacloprid on the level of urea, creatinine, uric acid and total protein in the serum of males Wister albino rats

\begin{tabular}{ccccc}
\hline Time (hr.) & Urea (mg/dl) & Creatinine $(\mathbf{m g} / \mathbf{d l})^{\text {Uric acid (mg/dl) }}$ & Total protein (g/dl) \\
\hline Control & $28.00 \pm 2.16^{\mathrm{e}}$ & $0.75 \pm 0.03^{\mathrm{f}}$ & $5.68 \pm 0.11^{\mathrm{g}}$ & $7.25 \pm 0.10^{\mathrm{e}}$ \\
$\mathbf{1}$ & $38.00 \pm 0.82^{\mathrm{d}}$ & $0.92 \pm 0.04^{\mathrm{ef}}$ & $7.20 \pm 0.03^{\mathrm{f}}$ & $7.68 \pm 0.08^{\mathrm{d}}$ \\
$\mathbf{3}$ & $51.33 \pm 2.49^{\mathrm{c}}$ & $1.05 \pm 0.05^{\mathrm{e}}$ & $10.13 \pm 0.07^{\mathrm{d}}$ & $8.04 \pm 0.06^{\mathrm{c}}$ \\
$\mathbf{6}$ & $75.67 \pm 2.62^{\mathrm{a}}$ & $2.28 \pm 0.13^{\mathrm{a}}$ & $19.15 \pm 0.26^{\mathrm{a}}$ & $8.94 \pm 0.23^{\mathrm{a}}$ \\
$\mathbf{1 2}$ & $62.33 \pm 2.05^{\mathrm{b}}$ & $1.98 \pm 0.02^{\mathrm{b}}$ & $13.15 \pm 0.12^{\mathrm{b}}$ & $8.53 \pm 0.16^{\mathrm{b}}$ \\
$\mathbf{2 4}$ & $51.66 \pm 1.25^{\mathrm{c}}$ & $1.49 \pm 0.15^{\mathrm{c}}$ & $11.41 \pm 0.18^{\mathrm{c}}$ & $8.16 \pm 0.07^{\mathrm{c}}$ \\
$\mathbf{4 8}$ & $40.67 \pm 1.69^{\mathrm{d}}$ & $1.31 \pm 0.08^{\mathrm{d}}$ & $8.85 \pm 0.12^{\mathrm{e}}$ & $7.93 \pm 0.13^{\mathrm{cd}}$ \\
\hline
\end{tabular}

Values are mean $\pm \mathrm{SD}$ ( $\mathrm{n}=5$ /group).

Table 4. Acetylcholinesterase activity in liver and brain of male rats after single oral administration of imidacloprid ( $20 \mathrm{mg} / \mathrm{kg} \mathrm{b}$. wt.)

\begin{tabular}{lcccc}
\hline Time (hr.) & \multicolumn{2}{c}{ Liver } & \multicolumn{2}{c}{ Brain } \\
\cline { 2 - 5 } & $\mathbf{( n g / m l )}$ & Decrease (\%) & $\mathbf{( n g / m l )}$ & Decrease (\%) \\
\hline Control & $5.26 \pm 0.08^{\mathrm{a}}$ & - & $16.54 \pm 0.45^{\mathrm{a}}$ & - \\
$\mathbf{1}$ & $4.11 \pm 0.06^{\mathrm{b}}$ & 21.8631 & $11.995 \pm 0.09^{\mathrm{b}}$ & 27.4788 \\
$\mathbf{3}$ & $3.01 \pm 0.06^{\mathrm{c}}$ & 42.8707 & $9.67 \pm 0.13^{\mathrm{c}}$ & 41.5357 \\
$\mathbf{6}$ & $0.90 \pm 0.04^{\mathrm{e}}$ & 82.8897 & $3.07 \pm 0.51^{\mathrm{e}}$ & 81.4389 \\
$\mathbf{1 2}$ & $1.27 \pm 0.03^{\mathrm{e}}$ & 75.8555 & $3.705 \pm 0.26^{\mathrm{e}}$ & 77.5998 \\
$\mathbf{2 4}$ & $1.995 \pm 0.06^{\mathrm{d}}$ & 62.0722 & $6.215 \pm 0.12^{\mathrm{d}}$ & 62.4244 \\
$\mathbf{4 8}$ & $2.87 \pm 0.03^{\mathrm{c}}$ & 45.4373 & $9.03 \pm 0.37 \mathrm{c}$ & 45.4051 \\
\hline
\end{tabular}

Values represent the mean \pm SD. ( $n=5$ /group).

Earlier studies showed that oral administrations of IMI to albino rats were significantly altered AChE levels in different regions in brain, plasma, serum, liver and blood (Bhardwaj et al, 2010; Kishandar et al, 2010; Boily et al., 2013; Kapoor et al, 2014; Vohra et al, 2014). Vohra and Khera (2015) reported that the brain and plasma AChE activity in rats was significantly reduced at $1 / 22 \mathrm{LD}_{50}$ of imidacloprid.

Marzouk (2016) found that after $24 \mathrm{hr}$., rats treated orally with imidacloprid $\left(1 / 10 \mathrm{LD}_{50}\right)$, no changes were detected in brain AChE level, whereas a slight decrease was recorded in serum AChE.

\section{REFERENCES}

Abu Zeid, E.H., R.T.M. Alam, S.A. Ali and M.Y. Hendawid (2019). Dose-related impacts of imidacloprid oral intoxication on brain and liver of rock pigeon (Columba livia domestica), residues analysis in different organs. Ecotoxicol. and Environ. Safety, 167: 60-68.

Anonymous (1986). Cohort Software. Costat user's manual virgin 3.03. Bekley. Calif., UAS.

Arfat, Y., N. Mahmood, M.U. Tahir, M. Rashid, S. Anjum, F. Zhao, D. Li, Y. Sun, L. Hu, C. Zhihao, C. Yin, P. Shang and A. Qian (2014). 
Effect of imidacloprid on hepatotoxicity and nephrotoxicity in male albino mice. Toxicol. Reports, $1: 554-56$.

Balani, T., S. Aggarwal and A.M.M. Thaker (2011). Hematological and biochemical changes due to short term oral administration of imidacloprid, Toxicol. Int., 18 (1): 2-4.

Bhardwaj, S., M.K. Srivastava, U. Kapoor and L.P. Srivastava (2010). A 90 days oral toxicity of imidacloprid in female rats: Morphological, biochemical and histopathological evaluations. Food and Chem. Toxicol., 48 : 1185-1190.

Boily, M., B. Sarrasin, C. Deblois, P. Aras and M. Chagnon (2013). Acetylcholinesterase in honey bees (Apis mellifera) exposed to neonicotinoids, atrazine and glyphosate: laboratory and field experiments. Environ. Sci. and Pollution Res., 20 (8): 5603-5614.

Brunet, J.L., M. Maresca, J. Fantini and L.P. Belzunces (2004). Human intestinal absorption of imidacloprid with Caco-2 cells as enterocyte model. Toxicol. Appl. Pharmacol., 194 : 1-9.

California Environmental Protection Agency (2006). Imidacloprid, risk characterization document dietary and drinking water exposure 2006. Dept. Pest. Regulation, 1195.

Chaney, A.L. and E.P. Marbach (1962). Modified Reagents for Determination of Urea and Ammonia. Clin. Chem., 8 : 130-2.

Ellman, G.L., K.D. Courtney, V. Andres and R.M. Featherstone (1961). A new and rapid colorimetric determination of acetylcholinesterase activity. Biochem. Pharmacol., 7: 88-95.

Henry, R.J. (1964). Clinical Chemistry: Principles and Technics. Harper and Row Publishers, New York

Henry, R.J. (1974). Clinical Chemistry: Principles and Technics. ( $\left.2^{\text {nd }} E d.\right)$ Harper and Row Publishers, New York.

Kapoor, U., M.K. Srivastava and L.P. Srivastava (2011). Toxicological impact of technical imidacloprid on ovarian morphology, hormones and antioxidant enzymes in female rats. Food and Chem. Toxicol., 49 : 30863089.
Kapoor, U., M.K. Srivastava, P. Trivedi, V. Garg and L.P. Srivastava (2014). Disposition and acute toxicity of imidacloprid in female rats after single exposure. Food and Chem. Toxicol., 68: 190-195.

Kishandar, N., R. Kumar, C.T.U. Rani and P.J. Doss (2010). Studies on the effect imidacloprid toxicity on the acetylcholin esterase activity levels in different regions of brain of albino rat. Int. J. Agric. Environ. and Biotechnol., 3 (4): $377-380$.

Lehotay, S.J. (2007). Determination of pesticide residues in foods by acetonitrile extraction and partitioning with magnesium sulfate: collaborative study. J. AOAC Int., 90 (2): 485-520.

Marzouk, S.G.M. (2016) selectivity of nicotinoid insecticides. M.Sc. Thesis, Fac. Agric., Zagazig Univ., Egypt.

Matsuda, K., S.D. Buckingham, D. Kleier, J.J. Rauh, M. Grauso and D.B. Sattelle (2001). Neonicotinoids: insecticides acting on insect nicotinic acetylcholine receptors. Trends Pharmacol. Sci., 22: 573-580.

Mohany, M., G. Badr, I. Refaat and M. El-Feki (2011). Immunological and histological effects of exposure to imidacloprid insecticide in male albino rats. Afr. J. Pharmacol. Physiol., 5 (18): 2106-2114.

Moriya, K., K. Shibuya, Y. Hattori, S. Tsuboi and S. Kagabu (1992). 1-(6-chloronicotinyl)2nitroiminoimidazoline and related compound as potential new insecticide. Biosci. Biotech. Biochem., 56 (2): 364-365.

Rahman, M.F., M.K.J. Liddique and K. Jomil (2000). Acid and alkaline phosphatase activities in a novel phosphorothionate (RPR-11) treated male and female rats: evidence of dose and time dependent response. Drug Chem. Toxicol., 23 (3): 497-509.

Taliansky-Chamudis, A., P. Gómez-Ramírez, M. León-Ortega and A.J. García-Fernández (2017). Validation of a QuECheRS method for analysis of neonicotinoids in small volumes of blood and assessment of exposure in Eurasian eagle owl (Bubo bubo) nestlings. Sci. Total Environ., 595: 93-100. 
Timchalk, C., T.S. Poet and A.A. Kousba (2006). Age-dependent pharmacokinetic and pharmacodynamic response in preweanling rats following oral exposure to the organophosphorus insecticide chlorpyrifos. Toxicol., 220:13-25.

Tomizawa, M. and J.E. Casida (2005). Neonicotinoid insecticide toxicology: Mechanisms of selective action. Ann. Rev. Pharmacol. Toxicol., 45: 247.

Tomlin, C.D.S. (1997). The Pesticide Manual, $11^{\text {th }}$ Ed., British Crop Protection Council, Surrey, UK, 706-708.

Toor, H.K., G.K. Sangha and K.S. Khera (2013). Imidacloprid induced histological and biochemical alterations in liver of female albino rats. Pest. Biochem. and Physiol., 105: $1-4$.

Trinder, P. (1969). Determination of glucose in blood using glucose oxidase with an alternative oxygen receptor. Ann. Clin. Biochem., 6: 24-27.
Vassault, A., D. Grafmeyer, C. Naudin, G. Dumont, M. Bailly and J. Henny (1986). Protocole de validation de techniques. Ann. Biol. Clin., 44 (686): 45.

Vohra, P., K.S. Khera and G.K. Sangha (2014). Physiological, biochemical and histological alterations induced by administration of imidacloprid in female albino rats. Pest. Biochem. Physiol., 110: 50-56.

Vohra, P. and K.S. Khera (2015) Alterations in key enzymes and micromorphology of vital organs during exposure of imidacloprid in albino rats. Int. J. Adv. Res., 3 (3): 134-144.

Watanabe, E., K. Baba, H. Eun and S. Miyake (2007). Application of a commercial immunoassay to the direct determination of insecticide imidacloprid in fruit juices. Food Chem., 102: 745-750.

Yamamato, I., M. Tomizawa, T. Satio, T. Miyamoto and S. Kagabu (1998). Structural factors contributing to insecticidal and selective toxicity of nicotinoids and neonicotinoids. J. Pest Sci., $20: 33-40$.

\section{النشاط الإنزيمي والمسار الزمني للتوزيع الكمي لجرعة فمية من الايميداكلوبريد في أنسجة ذكور الجرذان \\ هبه عزت نصر ' ـ عطا على شلبي' ـ ديدير احمد راغب' ـ محمد يوسف هنداوي' ـ سيبستيان سواف' \\ ا ـ قسم وقاية النبات ـ كلية الزر اعة - جامعة الزقازيق - مصر

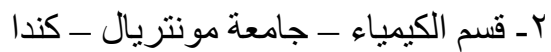

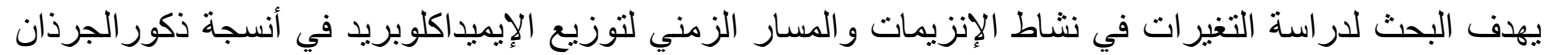

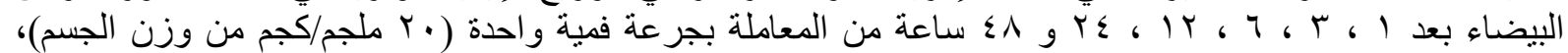

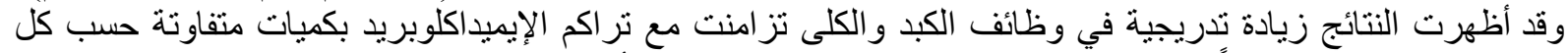

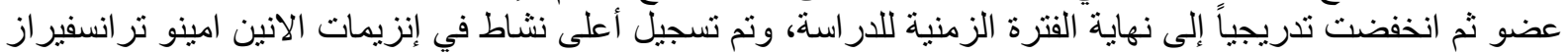

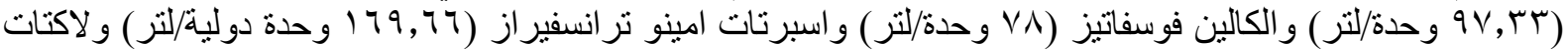

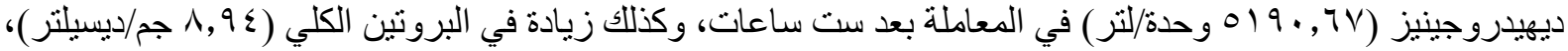

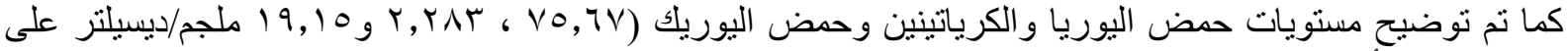

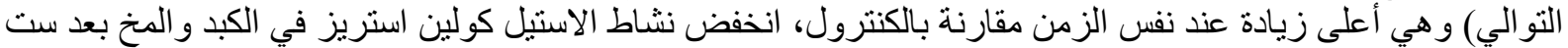

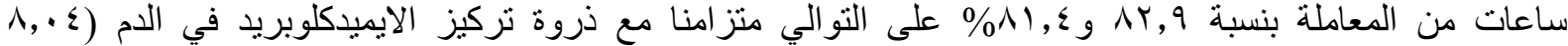

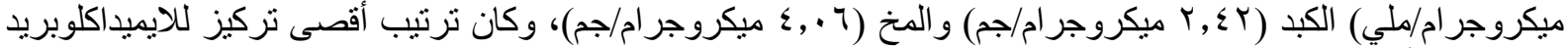

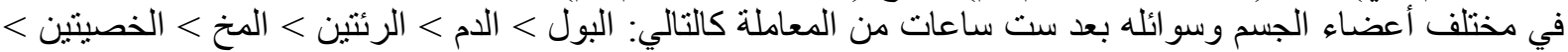
الطحال > الكلى > الكبد > العضلات. 